\title{
LATVIAN PLACE NAMES AND DIALECTS: A RELEVANT SOURCE FOR THE EXPLORATION OF THE VIDZEME SOUTH ESTONIAN LANGUAGE
}

\author{
Lembit Vaba \\ Saku, EE \\ phorest45@gmail.com
}

\begin{abstract}
Knowledge about the South Estonian language spoken in the parts of Livonia where Latvian prevailed is based on materials collected from the Leivus residing in Ilzene parish (Lv pagasts) of eastern Vidzeme. Very little language or none at all has been recorded from the South Estonian speakers who are known to have lived in the parishes bordering Ilzene. The article introduces and analyses the works of Latvian place name and dialect researchers focusing on Lejasciems and Kalnamuiža as well as Madona municipality (Lv novads) located in the southeastern corner of Vidzeme where South Estonians have historically lived.
\end{abstract}

Keywords: toponyms, etymology, Latvian dialects, South Estonian dialects, language islands

DOI: https://doi.org/10.12697/jeful.2021.12.2.08

\section{Introduction}

Knowledge about the South Estonian language spoken in Vidzeme is based on materials collected at greater or lesser intervals for more than a century from the Leivu community residing in the villages of Ilzene parish (Germ Ilsen) (see [1] in Figure 1) located in eastern Vidzeme. The foundations for reliable documentation and scientific analysis of the Leivu language were laid by Ferdinand Johann Wiedemann in his study "Die Ehsteninseln in den lettischen Kirchspielen Marienburg und Schwaneburg in Livland" (The Estonian islands in the Latvian church parishes of Marienburg (Alūksne) and Schwaneburg (Gulbene) in Livonia) when he had the opportunity to interview a local churchwarden (Et vöörmünder) of Leivu origin about the Ilzene Leivus in the summer of 1866 (for more see Vaba 1997: 52-53). From the other 
parishes bordering Ilzene, where the Leivu people are known to have also lived, there is very little, if any, recorded language material. A few text examples recorded by Finnish linguist Heikki Ojansuu in Andrini village in Lejasciems (Germ Aahof) parish (see [2] in Fig. 1) in 1911 are the exception. Most of these have now been published in the Estonian dialect series (Mets et al. 2014: 33-37). As part of this research expedition, Ojansuu also visited Ate village (Germ Ottenhof) in Anna parish (Germ Annenhof) [9] as well as Zeltini (Germ Seltinghof) [3] and Siduli village in Alsviki parish (Germ Alswig) [7] (see Fig. 1), though nothing significant was recorded there (Ojansuu 1912, Grünthal 1912: 325-326, Niilus 1937).

When the systematic documentation of the Estonian dialects began in the early 1920s, the South Estonian language - with a few exceptions was no longer in active use in the Leivu villages. Paulopriit Voolaine (1899-1985) was sent on a scholarship expedition funded by the Mother Tongue Society (Emakeele Selts) to document Leivu in 1921. However, he observed that there were no speakers with sufficient Leivu language proficiency remaining in Dūre (present-day Lejasciems parish) or Lìves (present-day Vireši parish), also no such speakers were found in Kalnamuiža parish (earlier Kalncempji [8], presently Stāmeriena parish [10]) or in Alsviķi parish (Germ Alswig) [7] (Koltsu or Kolcu and Tsiduli or Siduli villages), see Fig. 1). Therefore, it was only possible to document the language of the villages of Ilzene (Voolaine 1981: 101-106). The material that was collected and later comprehensively analysed by linguist Valter Niilus (1913-1978) during his language documentation expeditions also comes from the villages of Ilzene parish (Āžamuguri or Āžmugura, Brūniņi, Ilzene, Kārklupe, Melnupe, Paiķeni, Siveci, Onti) which he described being "like the strongest Leivu fortress" (kui leivude kõvema kantsi). In order to expand his circle of language informants, Niilus visited Andrini, Lapati, and Majāni villages in Lejasciems parish as well as Zeltini and Melnupe villages in 1936, but these efforts were largely unsuccessful (Niilus 1936). Other Estonian dialect researchers (Aili Univere, Salme Tanning, Mari Must, Salme Nigol, and others) were also using informants from Ilzene or - according to Valter Niilus from the strongest Leivu fortress. The last known speaker of Leivu was Antons Boks [1908-1988] from Kārklupe village in Ilzene parish (Vaba 1997: 50). 
Historical South Estonian settlements in Vidzeme

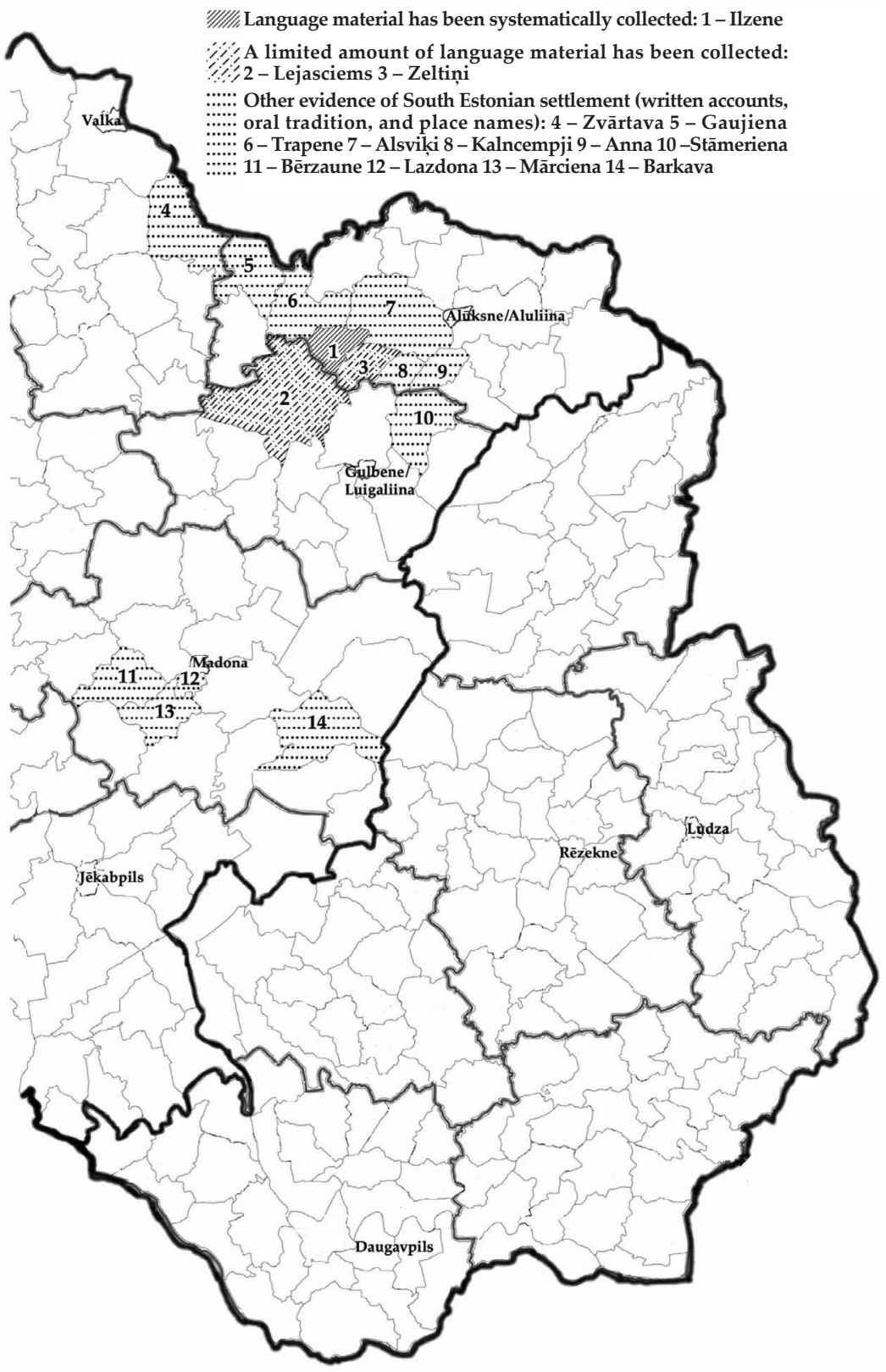

Figure 1. Historical South Estonian settlements in Vidzeme (marked with numbers in square brackets on a map of Latvian parishes). Map design and technical implementation: Väino Klaus. 
Written sources, local oral tradition, and place names suggest that the South Estonian island-like settlements in Eastern Vidzeme had a considerable population. There are groups of South Estonians in Vidzeme of which the only known traces in the present day are possible local place names of Estonian origin or sometimes also a brief ethnographic description jotted down by a former local pastor. For example, in 1784, Detlev Georg Meyer, pastor of the Atzele congregation (Gaujiena, [5] in Fig. 1), described the head coverings of the Estonian women and girls in his mixed Latvian-Estonian congregation: Estonian women wear high fur hats with round bottoms all year round, while Estonian girls wear straw wreaths decorated with tinsel and spangles (Stepermanis 1960: 228).

Considerably richer information is offered by Latvian sources on the South Estonians living in Lejasciems and Kalnamuiža as well as in Madona municipality (Bērzaune, Lazdona, and Mārciena) located in southeastern Vidzeme.

\section{What can Estonian place names tell us in Daina Zemzare's study Valodas liecības par Lejasciema novadu}

There are early ethnographic descriptions (from 1841) and rather sparse language descriptions from Lives village (Germ Liewe) in the former Lejasciems parish (for more see Vaba 1997: 50-52). The visits to the Lejasciems villages by Ojansuu, Voolaine, and Niilus were not fruitful for collecting language materials. Therefore, in my view Latvian linguist Daina Zemzare's study "Valodas liecības par Lejasciema novadu" (Language testimony about the Lejasciems region) (Zemzare 1940) deserves attention which, if carefully analysed, can provide important additional information about the Leivu language which has been extremely scarcely recorded at Lejasciems. The place name file of the Institute of the Estonian Language contains a rather modest Leivu slip file (290 slips), the majority of which consists of names from Ilzene with only a small number recorded in Lejasciems, primarily in Lives village. It should also be noted that the quality of the Leivu place name collection is rather variable. Unfortunately, Zemzare's work has not gained the attention of researchers of Estonian or other Finnic languages. Zemzare (1911-1971) was a versatile and prolific Latvian researcher, 
who, among other things, wrote studies on Latvian dialect vocabulary as well as place names and personal names. Zemzare began her field work in Lejasciems in the summer of 1935. She travelled through the villages of what was Lejasciems parish at that time (also Lives which was not a part of Lejasciems parish then or now) and documented names related to settlements, nature, and cultivation as well as the stories on the same topics. However, Zemzare paid greater attention to the villages of the Lejasciems region on the lands of the former Lejasmuiža state manor which are found in inventory books (Germ Wackenbuch) listing manor farms and their encumbrances dating from 1738, 1750, 1757 (Zemzare 1940: 31). The collected material was then supplemented by Zemzare with the help of the Domenni parish archives (from 1821 onward) and student notes from 1932 (stored at the Archives of Latvian Folklore (Latviešu fokloras krātuve)).

Zemzare writes that the people living along the Gauja River in Lejasciems parish as well as those in Ilzene parish and a part of those in Kalnciems parish can be considered descendants of Estonians. During her fieldwork, Zemzare met only a few older people who knew that their grandparents had spoken Estonian and that they also could not understand real Estonians either. Her Latvian-speaking informants assured Zemzare that Estonian had formerly been spoken in the villages of Andriņi, Ķibasi, Ķilpāni, Kručki, Majāni, Salaki, Suži, and Lapati. With the end of Estonian language knowledge, Estonian place names would either disappear completely or in the best case be replaced with translations, but in general Estonian place names are still well preserved, observes Zemzare (1940: 107). The part of Lejasciems where the descendants of Estonians live is referred to by other people in Lejasciems as "the black end" (màllais gòls, i.e., Lv std melnais gals); Zemzare theorises that this name may have come from the predominance of black colour in the clothing of the people there (Zemzare 1940: 3-4). À propos, a similar oral tradition survived in Kalnamuiža in the last century where "the black end" referred to the Estonians who lived there who wore darker clothing, had darker complexions and hair colour compared with Latvians (Balode \& Jansone 2017: 7). According to Zemzare, it is unclear whether the Lejasciems (and Ilzene) Estonians are native to this area or immigrants (Zemzare 1940: 5).

Zemzare's research indicates that the Estonians at the area left a noticeable mark on the place names of Lejasciems. This is especially 
evident in the word stems of place names of Estonian origin and perhaps also in derivational suffixes and topoformants. Lejasciems as well as Ilzene and Kalnamuiža are situated in the deep Latgalic subdialect area (Lv dzila latgaliska izloksne). Compared to Standard Latvian and the Central Dialect on which it is based, the most important innovations in the local subdialect have occurred in vocalism which also reached the Ilzene Leivu dialect and that are not, however, regular (Vaba 1997: 47-42, 54 etc.). The Estonian place names of Lejasciems have acquired the phonetic characteristics of the local Latvian subdialect; however, the changes in the vocalistic characteristics of the Latvian Eastern subdialects are not regular in Lejasciems. Some examples:

Lv std $a>\operatorname{Ltg} o$ : but Kadejs, Kadeja pù̀rs swamp, Ķilpāni village, cf. Ilzene kadaja $^{6} \mathrm{pl}, \mathrm{V}$ katai : kadaja 'juniper'; Làmbas plava meadow, Andriņi village, cf. Ilzene lamba pl, Et lammas : lamba 'sheep / Schaf'; Palana pùrs swamp Salaki village, cf. Ilzene palanu, V palanu 'burned out (place)'; Samèlpù̀rs swamp, Kručki village, cf. V sammaì: sambla 'moss'; Sarapi farmstead, Lapati village, cf. Et sarap 'hazelnut tree'; Saviku plava field, Čipati village, cf. Et savi 'clay'; Vanateri farmstead, Lapati village, cf. Ilzene vana vona, Et vana : vana 'old'; Vachceteri farmstead, Salaki village, cf. Ilzene vastnõ : vahtsõ, V vahtsõnõ : vahtsõ 'new');

Lv std $\bar{a}>\operatorname{Ltg} \bar{o}>u o$ : but $\grave{A} v a(s)$ kòlls hill, Salaki and Andrini villages, cf. V haab : haava 'aspen (tree)'; Lànupes kòlls hill, Lànups drova field, Salaki village, cf. V laas : laane 'a large dense forest / dichter Laubwald auf feuchtem Boden'; original $\bar{a}$ developed into a diphthong which varies considerably in the local subdialect: ${ }^{\circ} \bar{a}$ (Lejasciems), $и o \sim u a$ (Zeltinin), see Endzelīns 1951: 125;

Lv std $\rho$ [ä] > Ltg $a$ : Janeze field, Majāni village, cf. Et jänes : jänese 'hare'; Magi hill, Salmaņi village, cf. Et mägi : mäe 'hill'; Makra kòlls Makarkòlls pasture, Kručki village, cf. Ilzene mäkr : mägra, Et mäger : mägra 'badger / Dachs'; Parànda (? < *pęręnd-) pùrrs swamp Ķilpāni village, ? cf. M põreńd : põrendi 'fire for clearing land for farming (slashand-burn agriculture), large fire' Tanning 1958: 109; Varatkolls hill, Čipati and Lembji villages, cf. Ilzene plg värete, $\mathrm{V}$ väreht' : värehti 'gate', but Lepans $\sim$ Lepans hill slope, Majāni village, ? cf. Et lepp : lepa 'alder');

6 Estonian dialect examples without a referenced source are from the following publications: EMS, Käis 2011, MES, Pall 1982-1989. Examples are presented in the Estonian orthography; palatalisation is also marked. 


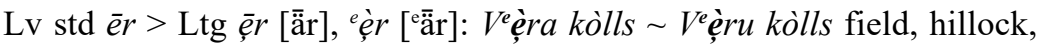
mound, Umari village, cf. V viiŕ : veere 'edge, shore';

Lv std $\bar{l}>$ Ltg ei: Lèives village, Lèivùrga field, Dukuḷi village, cf. Et liiv : liiva 'sand'; Pèirenîca, but Pìrenîca $\sim$ Pìra meadow, Salaki village, ? cf. $\mathrm{V}$ piiŕ : piiri 'border, boundary'; Tèigùrga meadow, Lapati and Ķilpāni villages, Tèigurga river, Lapati village, ? cf. V tiik: tiigi 'pond / Teich', but Linceḷmola field, Lembji village, ? cf. V liin : liina 'town; hill fort';

Lv std $\bar{u}>$ Ltg ou: but Sūretere farmstead, Salaki village, cf. Ilzene sour : sourõ, V suur : suurõ 'large').

The reasons for these two different patterns in vocalism are not yet completely understood. In Zemzare's opinion, place names in which the expected dialectal vowel changes do not occur belong to a somewhat newer stratum (Zemzare 1940: 108). I think, however, that more likely the main reason is the Standard Latvian influence which at that time had already become familiar and known to local people at school and church. Zemzare also agrees with this. Also, we should not disregard the fact that the interviews with the informants probably took place in Standard Latvian (the interviewers were not speakers of the local subdialect) - a situation which, as is well known, always inclines the informants towards the standard language. In dialects the preservation of the original vocalism may be a result of the sound environment. For example, in the Eastern Latvian dialect, original dialectal $a$ can be maintained in front of $v$, front vowels, and elsewhere which might explain the persistence of $a$ in the names Saviki, Saviku plava, Sàvika pùriņš, Kadeja pù̀rs, Samèlpùrrs (about Eastern Latvian dialect vocalism see Rudzīte 1964: 267, etc.). Paul Ariste (1931: 175-179) attempted to explain the differences in the innovations in Ilzene and Lejasciems Leivu vocalism. In Ariste's approach, the relatively consistent diphthongisation of the original long vowels $\bar{l}$ and $\bar{u}$ that are characteristic of Eastern Latvian occurred differently in Ilzene (Zeltini parish) than in Lejasciems, because the Estonians had lived there for a longer period of time and had been in intensive contact with Latvians for longer than the Estonians in the neighbouring area. In Ariste's opinion, the contradiction that accompanies this hypothesis - why Estonian language survived the longest in Ilzene - is explained by the fact that Ilzene was 
separated from Latvian settlements by forests and swamps. However, if the starting point of the discussion is that the local Estonians are indigenous inhabitants, then, of course, Ariste's view is not correct.

Zemzare feels that the vowel $o$ [ŏ] in Lejasciems place names may be of diagnostic value in determining whether a name is of Finnic origin (Zemzare 1940: 108), though the structurally unusual $o$ in this Latvian subdialect is not constant, also because original $a>\operatorname{Ltg} o$ : Kòlgamasas pùrrs (swamp), Kònčura kòlls (hill), etc., Konukòlls (hill, meadows), Oja $[\breve{o}]$ meadow, Čruze $\sim$ Čorize $[\breve{o}]$ river, field.

Lejasciems place names of Estonian origin have mostly been adapted to the Latvian morphological system, but there are several interesting exceptions. Zemzare has recorded place names where the suffix contains the final vowel $i$ which is unusual in the Latvian context and can be interpreted as a masculine plural nominative in this specific context, e.g., Jànišǔc (the morphologically adapted parallel form is $J^{0}$ ànušòuki $i(s)$ ) [- $n$ - sic!] field, Peki kolls (the morphologically adapted parallel form is Peķa kòlls) field, Maǵi kòlls hill, Ruvi cel̦̆ road, Sànki kòlls hill. The suffixes of Latvian compound names are in genitive (either singular or plural), therefore, morphologically the Latvian versions of these examples would have been *Maǵu kòlls, *Ruvu celšs, *Sànku kòlls. In the Livonic dialect of Latvian, compound words with nominative suffixes have been recorded and these follow the same Finnic word formation model (see Rudzite 1964: 202). Zemzare explains the instability of the grammatical gender of Lejasciems compound word suffixes (e.g., $\bar{A} v a<\mathrm{m}>\sim \bar{A}$ vas $<\mathrm{f}>$ kòlls hill) as well as the dominance of the masculine gender with the influence of Estonian (Zemzare 1940: 108). Zemzare correlates kene- ending place names with Estonian kenecompound appellatives: e.g., Làudakenes kokts an area in Salaki village, ? cf. Et laudakene dim. 'cattle-shed'; Palukene meadow, forest, cf. Et palukene dim. 'dry pine forest'; Tamakene thick pine forest, meadow, cf. Et tammekene dim. 'oak'. In my opinion, Ilzene (and South Estonian) linguistic innovations include abundant use of diminutives, analysis of Lejasciems names cannot ignore the highly productive Latvian inš-noun formation model $(<*$-inis $)$ which may have been used as a model in Lejasciems, because in the modern language, Latvian inšs-words coincide with diminutives with the same ending.

In studying the etymology of Lejasciems place names, Zemzare has promoted the view that each place name had a meaning at the time 
it was given which seeks to describe the object that is being named. For Lejasciems names unclear in the Latvian (Baltic) context, Zemzare attempted to find sound structural correspondences or similar Estonian appellatives, occasionally also using (South) Estonian place names or first names to support the proposed appellative. When attempting to determine the etymology of place names, hypotheses always need to be viewed with a reasonable degree of scepticism and make me think of walking on thin ice; however, the approach that a place name is formed directly from an appellative does not always give a sufficiently convincing result. I find comparisons such as these offered by Zemzare questionable: Isa field, meadow, İsas pùriņš swamp, cf. Et isa, Ilzene esä 'father / Vater', Ivika İvika pù̀rs swamp, cf. Et ivikas : ivika 'grainy / körnig, körnreich', Kaklica kakts an area in Līves village, cf. Et kaklus : kakluse 'quarrel, scuffle, brawl / Streit, Balgerei, Rauferei', Kamàldina river, cf. Et kamal 'double handful / Gäspe', kammal 'cupped hands / Faust mit beyden Händen', K̦ệriki village, cf. Et kerik, kirik, Ilzene kièrik 'church', Killpani village, cf. Et kilp : kilbi 'shield / Schild', Kuniks Kuñika, Kunika pùrs meadow, cf. Et kuńn : kuńní 'a small, cylindrical piece of wood / kleines, zylenderförmiges Holzstück, kuńniks 'how long / wie lange', Šilmists field, cf. Et silmist ära 'blind / blind', etc. By slightly correcting and adjusting the etymologies proposed by Zemzare as well as adding new ones, I can propose based on the preliminary analysis that the place names collected and published by Zemzare contain over a hundred appellative word stems of possible Estonian origin. It is important to emphasise that in most cases they have a corresponding appellative in the South Estonian (V) dialect.

Some examples: Janeze field: Ilzene d’ännen : d’äneza, V jäneśs : jänese 'hare'; Ceri(k)pulda field: Ilzene V põld : põllu 'field'; Kadejs Kadeja pùrs swamp: Ilzene kadaja pl, V katai : kadaja 'juniper'; Kašenīca Kašeñica meadow, Kašinîte meadow: Ilzene kašš : kaš́i, V kaśs : kaśsi 'cat'; Kugru kòlls field, flax retting pool: Ilzene kukr : kugrõ, V kogõó : kogrõ 'crucian carp (Carassius carassius)'; Nakrìms field, pasture: Ilzene nakr : nakrõ, V nakõr' : nakrõ 'turnip'; Palana pùrs swamp: Ilzene palanu, V palanu 'burned out (place)'; Punačš $\sim$ Punaču kòlli hills, Punača pù̀rs swamp: V punanõ : punadsõ 'reddish-brown'; Sùlgîtajs $\sim$ Sùlgîtitis $\sim$ Sùlǵga pùrs swamp: Ilzene sulu- 'flax retting pool', V sulg : sulu 'sluice, barrier, dam; Suža plava meadow and Suža pùrs swamp: Ilzene suž'i : soe, V susi : soe 'wolf'. 
In a string of cases, there is a corresponding appellative in the Mulgi dialect (M), but none in the Võro dialect: Ivika pù̀rs İvika pùrrs swamp: M jõhvik 'sedge, marsh carex (Carex acutiformis): a swamp grass reminiscent of horsehair; hardy fescue (a hardy grass that grows on dry meadows); bristle oat (Avena strigosa)', the source of the loan iviks 'màllgalvîši, lit., black heads (a type of plant)' recorded in the Lejasciems Latvian subdialect is the same as the plant name jõhvik given here, not, as Zemzare thought ivikas 'grainy / körnig, körnreich', ivike 'grain, seed / das Körnchen, der Same'; Loisi field, cf. M loisk: loisu 'a low-lying, wet place; water puddle'; Makra kòlls $\sim$ Makarkòlls pasture, cf. Ilzene mäkr : mägrä, M mäger : mägrä 'badger'; Parànda pù̀rs swamp, ? cf. M põreńd : põrendi 'fire for clearing land for farming (slash-and-burn agriculture), large fire' Tanning 1958: 109; Ruvi celı̆ road, cf. ruhi : V rohe $\sim \mathrm{M}$ ruhvi 'dugout boat'; Tilgasa pùrs, Tìlka(s) pù̀rs and Ķilka $(?<$ tilka) pù̀rs $\sim$ Škùsta pù̀rs swamp, cf. M tilk : tilga: kesätilk 'spring shoots of the field horsetail', Lv skùste $\sim$ škùste 'field horsetail (a type of plant) / Schachtel, Schafthalm'.

Zemzare tried to highlight the Estonian derivational suffixes found in the Lejasciems place names (Zemzare 1940: 108); however, due to the researcher's modest knowledge of language and limited understanding of Estonian word derivation, the analysis is mechanical, and the result is more than questionable. Some derivational suffixes characteristic of Estonian place names, i.e., topoformants, can be identified, however, with considerable certainty:

-ik: Kuṇiks Kuṇika, Kuṇika pù̀rs meadow, Làudiķis forest, Nìstiķis field, forest, Nùrneķis $\sim$ Nurmikis field, meadow, Pịlika kràujs ravine, Saviks, Savika kòlls field;

$-m$ and $-m(a)$ : Magim(a) meadow, Màigima kòlls field, Matuma kòlls hill, Pitèrma meadow, Nakrìms field, pasture, Sùrums swamp; -ndV: Kàvàndasùlg brook;

-st(V): Kaṇista kàlliņ̌s, Kanists meadows, Kìvists $\sim$ Kìvèsts pasture, Palastene, Šilmists field; -ts(V): ? Tinačš $\sim$ Tinača brook, flax retting pool.

Further careful analysis may reveal the contents of these place names as well as appellatives, derivational suffixes, topoformants, etc., which have escaped attention up until now. 


\section{Estonian language material in the Kalniena (Kalnamuiža) subdialect dictionary}

August Wilhelm Hupel was the first to describe the Leivu people in print, while also being the first to assert correctly that they are South Estonians, not Livonians. In 1782, he wrote the following about the Estonian settlements in the area of Kalnamuiža or Kalniena (Kalncempji, in present-day Stāmeriena parish) in his well-known work "Topographische Nachrichten von Lief- und Ehstland" (Hupel 1782: 212-213): "In dieser Gegend geht ein Strich ehstnische Wohnungen mitten durch die Letten, von Kalnamuisch zwischen Seltinghof und Marienburg über Treppenhof und Adsel nach Walk, der einige tausend Bewohner hat, lauter wahre Ehsten, die sich unvermischt zusammen halten. Ihre Weiber schneiden wie die am Peipus-See, die Haare ab, sobald sie verheirathet sind. Wenn sich diese dahin gezogen und dort niedergelassen haben, ist mir unbekannt."

In 1815, the Alūksne pastor Otto Friedrich Paul von Prühl compiled a list of Kalnamuiža farmsteads inhabited by Estonians (34 farmsteads) who also understood Latvian but spoke it poorly. August Bielenstein (1892: 19-20) confirmed this information about the Kalnamuiža Estonians explaining that in Kalnamuiža, which belongs to the Zeltini filial church, there is a certain number ("eine Anzahl Ehsten") of mostly Latvianised Estonians. According to the 1811 Livonian governorate revision lists (Lv dvēselu revizijas, lit. soul revisions), there were 66 farmsteads in Kalnamuiža, therefore, Estonians had to have lived in more than half of these households (Balode \& Jansone 2017: 6-7). According to Ojansuu, who also visited Kalnamuiža during his 1911 expedition, only very few still spoke Estonian by that time: he reports a total of 9 men and women who lived in the villages of Laud'i ( $\mathrm{Lv}$ Lauķi), Lüğäbä, Gotliba (Lv Gotlupi) (Ojansuu 1912: 7-26, quoting a source in Estonian: Grünthal 1912, 322, 325). Communities classified by Voolaine in 1921 as Leivu villages in Kalnamuiža parish included Uranužõ (Lv Uranaži), Paĺži, Mõtspalži, Bulki (Lv Melderpulḳi, also,

7 Translation: In this area, there is a line of Estonian settlements right through the middle of the Latvians, from Kalnamuiža between Zeltini and Alūksne over Trapene and Adzele to Valka which have a few thousand inhabitants, all true Estonians, who stick together unmixed. Their women cut their hair as soon as they are married, just like those by Lake Peipsi. When they moved and settled there, is unknown to me. 
Puļ̣,i), Spriuli or Preili (Lv Sprīvuḷi), Laudi (Lv Lauķi), Gotlubi (Lv Gotlupi), and Lügäbä; Voolaine found "barely five people who knew a little bit of the Leivu dialect" in this parish (Voolaine 1981: 106).

The Kalnamuiža Estonians have left a significant impression on the local Latvian subdialect, as can be seen from the analysis of the recently published "Kalnienas izloksnes vārdnīca" (Dictionary of the Kalniena subdialect) (Balode \& Jansone 2017) compiled by Sarmìte Balode and Ilga Jansone. The Kalniena subdialect belongs to the High Latvian Vidzeme subdialect group but its speakers appear to distance themselves and sharply contrast with the Latgalians: ćàygaḷi jàu ìr àtras dabas, àtri suôk kaûtîs, čàngaḷ us navàr kàitinât ' the čangaḷi (Latgalians) have a moody character, they are quick to fight, the čangali should not be irritated' (sub čàngalis). The Kalniena subdialect is characterised in particular by a number of developments in vocalism, many of which can also be seen in the linguistic novelty encountered in the Leivu spoken in Ilzene, for example, $a>o, \bar{e}>i e, \hat{\imath}>e i, \hat{u}>o u$, in some words $i>u$. Most of the material in the Kalniena dictionary was collected during 1977-2013. The dictionary includes specific local vocabulary and a significantly wider range of dialect and shared vocabulary. Finnic, including South Estonian, influence can be detected at all levels of language. In this article I highlight the vocabulary that are possible (South) Estonian loan words (i.e., substrate words) which have not yet been noted in Latvian lexicographic sources or not identified as loans, for example, cekecs ' $s$-shaped iron for cutting up grass', cf. eS tsagiraud ' $s$-shaped iron for chopping or hacking (feed); chopper', tsagama 'to chop up finely', čogas $\mathrm{pl}$ 'pressed berry waste; pressed flax seeds', cf. Et soga 'mud, muck', sagu 'remainders at the bottom of a pot, dregs in some kind of a liquid at the bottom of a pot, draff', ičiks 'chicken (or other bird) gizzard', cf. eS (h)õdsik id., kirdavacka 'flat round bread made of course-ground wheat or barley (Lv karaša)', cf. eS kõrd: kõrdleib 'bread with stripes made from other ingredients' + vatsk 'wheat, barley, or rye flat cake (which often contained potato or groat porridge, split hemp seeds, etc.)', sobinas: iêst s 'to eat something better than others', cf. Et sobi 'fraud, deception'. Other substrate phenomena include abstract nouns as well as nominals with other semantics which, following the example of Estonian, can occur in the dialect as singular forms instead of the expected plural forms, e.g., bàda 'sorrow, suffering, misfortune', Lv std bēdas $\mathrm{pl}$, brìsma 'very large, terribly large', 
Lv std briesmas $\mathrm{pl}$ 'danger, horror', šàusma 'very large, terribly large', Lv std šausmas pl 'horror'. Like Latvian more broadly, in addition to prefix verbs, the Kalniena subdialect is also characterised by verb and adverb units (phrasal verbs) and prefix verbs which are accompanied by adverbs of the same meanings. The Finnic influence is clear in speech, e.g., apkìort abgrîza motus 'the hair was cut around', àr tîm [rijas] gruôbeklîm nùkratija sòlmus nûst 'with those [threshing barn] rakes, the straw was shaken off, pìadît kluô 'to knit on to', sadzina grầdus kùpâ 'pushed the grains together', viersâ uzliêja cimànta javu 'poured the cement mortar onto (it)' (see Vaba 2018: 151-153).

\section{Estonian names in Bērzaune, Lazdona, and Mārciena parish place names?}

In the study mentioned earlier, Bielenstein briefly described three other groups of Estonians known to him: the Estonian-speaking Ilzene parish, the approximately 500 Estonian inhabitants of Lejasciems, and the residents of Mārciena (see [13] on Fig. 1) manor in Bērzaune (see [11] on Fig. 1) parish, "who differ considerably in terms of physiognomy, clothing, and character from their neighbours living around them, but whom they still call Tschūdi (cf. Ru Чудь, Tschude, Eestlane 'Estonian') even though they speak and have long spoken Latvian" (Bielenstein 1892: 19-20). As is known, чydb refers to all Estonians in Russian chronicles beginning in the 11th century. Little is known about the Estonians who lived within the boundaries of what are now the Mārciena and Bērzaune parishes, located in the southern part of the Selonic subdialect area in Madona municipality in the southeastern corner of Vidzeme. Latvian place name researcher Ojārs Bušs considers the place names Kaisitis (lake), Subra, Úsmani, perhaps also Parkas and Irel̦i (farmstead names) as possible evidence of Estonian settlement in Mārciena. According to Bušs, there is a great likelihood that the village names Siksala, Raksala or Rāksola, Čibestēni $(<*$ Kibestēni) and the forest name Riste - located across the Aiviekste River in Barkava parish (see [14] in Fig. 1) in Latgale - are of Estonian (Finnic) origin. Bušs has also found and highlighted possible traces of Estonian settlement in Lazdona (see [12] in Fig. 1) parish. These are: Sāmalas or Sāmalu purvs (swamp), Niras or Niras ezeriņ̌s (lake), and perhaps Kuja (river) 
which earlier Latvian place name researchers have also considered to be place names of Finnic origin (Bušs 2006; see also Vaba 2019: 60). Traces of an Estonian or more general Finnic substrate in the phonetics of the Selonic subdialects which, according to Latvian dialect researcher Maija Poiša (1985: 191), are particularly evident from the presence of transitional vowels at the beginning of words facilitating pronunciation and less often also within word-internal consonant sequences (anaptyxis), seem to support the Estonian, i.e., Finnic, origin of these place names. Poiša's hypothesis concerning observable Estonian (Finnic) traces in the phonetics of the Selonic subdialects would require the presence of significant past South Estonian (Finnic) settlement in this area. A migration hypothesis, however, would mean a considerable migration to this area in the past. Niilus has also played with the notion that the southern boundary of the Leivu-inhabited region may also have reached that far south in antiquity, i.e., approximately $110 \mathrm{~km}$ from the border of Estonia and 60-70 km from the Gauja Estonians. He added that "perhaps research into old place names will give a precise answer regarding the area formerly inhabited by the Leivus" (Niilus 1935: 368,370 ). According to the archaeological data, the extent of the South Estonian-inhabited region, e.g., in the Early Iron Age (1st-5th centuries A. D.), extended only into present-day northern Latvia (Jaanits et al. 1982: 245). Systematic study of the Selonic subdialects and place names of this dialect area, especially that of Mārciena, Lazdona, and also neighbouring parishes, would undoubtedly reveal new Estonian (Finnic) place names and would make it possible to provide a clearer picture of the extent of possible Estonian (Finnic) settlement in the region and perhaps also of its linguistic character.

\section{Conclusion}

In this article I introduced and presented a preliminary analysis of the print materials published by Latvian place name and dialect researchers with a focus on Lejasciems, Kalnamuiža, and the southeastern corner of Madona municipality which were historically inhabited by South Estonians. My aim was to show that the work of Latvian linguist Daina Zemzare on the place names of the Lejasciems region offers an important contribution to Estonian dialect research on the Leivu language spoken in the area. One of the key questions is the occurrence of two 
different patterns in the vocalism of the place names of Estonian origin in Lejasciems, the reasons for which are not completely clear. By correcting and adjusting the etymologies proposed by Zemzare as well as adding new ones, it is possible to conclude that the place names of Lejasciems contain over a hundred appellative word stems of possible Estonian origin. In most cases they have a corresponding form in the South Estonian (Võro) dialect.

The recently published Kalniena subdialect dictionary provides an opportunity to obtain information about the South Estonian substrate spoken in the area. A preliminary analysis of the dictionary makes it possible to state that the Kalnamuiža Estonians have left a significant mark on the local Latvian subdialect.

There is an indisputable Estonian, i.e., Finnic, layer in the place name inventory of Madona municipality located in the southeastern corner of Vidzeme. This fact is supported by the occurrence of transitional vowels at the beginning of words facilitating pronunciation, and less often also within word-internal consonant sequences which is characteristic of the subdialect spoken in the municipality. However, it is not clear whether this is an old South Estonian, i.e., Finnic population, or the result of a later migration.

\begin{abstract}
Abbreviations
dim. - diminutive; Et - Estonian; eS - South Estonian; f - feminine; std - standard language; Lv - Latvian; Ltg - Latgalian; $\mathrm{m}$ - masculine; $\mathrm{M}$ - Mulgi dialect; $\mathrm{pl}$ - plural; plg - plural genitive; Germ - German; $\mathrm{V}$ - Võru dialect; $\mathrm{Ru}$ - Russian
\end{abstract}

\title{
References
}

Ariste, Paul. 1931. Lisandeid Koiva murrete vokaalide häälikuteloole. Eesti Keel 10(6). 175-179.

Balode, Sarmīte \& Ilga Jansone. 2017. Kalnienas izloksnes vārdnīca 1. Rīga: LU Latviešu valodas institūts.

Bielenstein, August. 1892. Die Grenzen des lettischen Volksstammes und der lettischen Sprache in der Gegenwart und im 13. Jahrhundert. Ein Beitrag zur ethnologischen Geographie und Geschichte Russlands. St. Petersburg: Buchdruckerei der Kaiserlichen Akademie der Wissenschaften. 
Bušs, Ojārs. 2006. Somugrismi Latvijas toponīmijā: Nesastādītā saraksta papildināšanas iespējas. Letonikas pirmais kongress. Valodniecības raksti, 121-129. Rīga: Latvijas Zinātṇu akadēmija.

Endzelīns, Jānis. 1951. Latviešu valodas gramatika. Rīgā: Latvijas valsts izdevniecība. Grünthal, V[illem]. 1912. Eesti asundused lätlaste seas. Eesti Kirjandus 7(8). 320-338, 369-373.

Hupel, August Wilhelm. 1782. Topographische Nachrichten von Lief- und Ehstland. Gesammelt und herausgegeben durch August Wilhelm Hupel. Dritter und letzter Band. Riga: Johann Friedrich Hartknoch.

Jaanits, Lembit, Silvia Laul, Vello Lõugas \& Evald Tõnisson. 1982. Eesti esiajalugu. Tallinn: Eesti Raamat.

Käis, Inge. 2011. Vanapärase Võru murde sõnaraamat. Rõuge, Vastseliina, Setu. Tallinn: Eesti Keele Sihtasutus.

Mets, Mari, Anu Haak, Triin Iva, Grethe Juhkason, Mervi Kalmus, Miina Norvik, Karl Pajusalu, Pire Teras, Tuuli Tuisk \& Lembit Vaba. 2014. Lõunaeesti keelesaarte tekstid (Eesti murded IX). Tallinn: Eesti Keele Instituut, Tartu Ülikool.

Niilus, Valter. 1935. Leivu rahvas. Eesti Kirjandus 29(8). 365-381.

Niilus, V[alter]. 1936. Märkmeid. Leivu (Ilzeni, Paikēeni). (AES 191). http://emsuka.eki.ee.

Niilus, V[alter]. 1937. Heikki Ojansuu lõuna-eesti murdekogudest. Eesti Keel 16(5). $140-145$.

Ojansuu, Heikki. 1911. Leivu murdetekste. Koopia Heikki Ojansuu Soome Kirjanduse Seltsi Estica V leiduvaist originaalest. [Kopeerinud Valter Niilus 1937.] (ES MT 198) http://emsuka.eki.ee.

Ojansuu, Heikki. 1912. Virolaiset siirtokunnat lättiläisalueella, niiden lähtöpaikka ja -aika. Suomalainen Tiedeakatemia. Esitelmät ja pöytäkirjat. Helsinki 1912, 7-26.

Pall, Valdek (ed.). 1982-1989. Väike murdesõnastik I-II. Tallinn: Valgus.

Poiša, Maija. 1985. Tšerty livonskogo dialekta v selonskih govorah. Problemy etnitšeskoj istorii baltov. Tezisy dokladov mežresp. nautšnoj konferentsii, 191-193. Rīga: Zinātne.

Rudzīte, Marta. 1964. Latviešu dialektologiija. Rīgā: Latvijas valsts izdevniecība.

Stepermanis, Marǵers. 1960. Nekotorye itogi poslednih ekspeditsij etnografov Akademii nayk Latvijskoj SSR v Severnom Vidzeme. Etnograafia Muuseumi Aastaraamat XVII. 225-233.

Tanning, S[alme]. 1958. Mulgi murde ja liivi keele suhetest. Keele ja Kirjanduse Instituudi uurimused II, 105-117. Tallinn: Eesti Riiklik Kirjastus.

Vaba, Lembit. 1997. Uurimusi läti-eesti keelesuhetest. Tallinn-Tampere: Eesti Keele Instituut, Tampereen yliopiston suomen kielen ja yleisen kielitieteen laitos.

Vaba, Lembit. 2018. Sarmīte Balode, Ilga Jansone. Kalnienas izloksnes vārdnīca 1-2. Rīga: LU Latviešu valodas institūts 2017. Linguistica Uralica 54(2). 151-153.

Vaba, Lembit. 2019. Welche Sprache sprechen Ortsnamen? Über ostseefinnischbaltische Kontakte in Abhandlungen über Toponymie von Ojārs Bušs [The Revealing Language of Place Names: Finnic-Baltic Contacts According to the Toponymic Studies by Ojārs Bušs]. Linguistica Uralica 55(1). 47-65. https://doi. org/10.3176/lu.2019.1.05. 
Voolaine, Paulopriit. 1981. Esimest korda leivude juures. Emakeele Seltsi aastaraamat 25, 99-106. Tallinn: Eesti Raamat.

Zemzare, Daina. 1940. Valodas liecības par Lejasciema novadu. Savākusi un apstrādājusi mag. phil. Daina Zemzare. Rīga: VAPP Praktisko zinātṇu apgādniecība.

\section{Online resources}

EMS = Eesti murrete sõnaraamat. http://www.eki.ee/dict/ems/.

MES = Mulgi sõnastik. http://www.eki.ee/dict/mulgi/.

Kokkuvõte. Lembit Vaba: Läti kohanimed ja murded: asjakohane allikas Vidzeme lõunaeesti keele uurimiseks. Teadmised lätikeelsel Liivimaal kõneldud lõunaeesti keelest rajanevad ainestikul, mida on kogutud Vidzeme idaosas Ilzene valla külades elanud leivudelt. Ilzenega piirnevatest valdadest, kus teadaolevalt elas samuti lõunaeestlasi, on keeleainest talletatud napilt või üldse mitte. Artiklis analüüsitakse neid Läti kohanime- ja murdeuurijate töid, mis on seotud Lejasciemsi ja Kalnamuiža ning Vidzeme kagunurga Madona piirkonnaga, kus ajalooliselt on elanud lõunaeestlasi.

Lejasciemsi vallast talletatud keeleaines on sedavõrd kasin, et eesti ja teiste läänemeresoome keeleuurijate huvi peaks väärima Läti keeleteadlase Daina Zemzare töö „Valodas liecības par Lejasciema novadu” (1940), mis hoolika analüüsi korral pakub olulist lisa Lejasciemsi valla külades kõneldud leivu keele kohta. Liiatigi sisaldab Eesti Keele Instituudi kohanimekartoteek väga tagasihoidliku ja ebaühtlase kvaliteediga Leivu sedelkogu (246 sedelit), kus Lejasciemsi nimesid on vaid vähesel määral, sealjuures peamiselt Līvesi külast. Välitöödel teadsid Zemzare keelejuhid kinnitada, et eesti keelt räägitud vanasti Andriņi, Ķibasi, Ķilpāni, Kručki, Majāni, Salaki, Suži ja Lapati külas. Zemzare võis siiski tõdeda, et eesti kohanimed olid tollal (1930ndate teine pool) Lejasciemsis veel hästi säilinud. Zemzare arvates pole selge, kas Lejasciemsi ja Ilzene eestlased on siinse piirkonna põlisasukad või sisserändajad.

Zemzare uurimus osutab, kui tähelepandava jälje on sealsed eestlased jätnud Lejasciemsi kohanimistusse. See ilmneb eelkõige kohanimedes esinevates eesti päritolu sõnatüvedes ning võib-olla ka tuletusliidetes ja topoformantides. Lejasciems on sügava latgali murdekeele (läti dziļa latgaliskā izloksne) ala. Võrreldes läti ühiskeele ja selle baasiks olnud keskmurdega on siinse murdekeele olulisimad innovatsioonid toimunud vokalismis, mis tulevad esile ka Lejasciemsi eesti päritolu kohanimedes, kuid siiski mitte järjekindlalt. Vokalismis avalduva kahetise esinemuse põhjused pole lõpuni selged. Zemzare arvates esindavad kohanimed, milles ei ole ootuspäraseid murdeomaseid 
vokaalimuutusi, suhteliselt uuemat nimekihistust. Peapõhjuseks tuleb siiski pidada läti kirjakeele mõju, mis tollal oli kooli ja kiriku kaudu saanud siinsele rahvale omaseks. Ilzene ja Lejasciemsi leivu keeleuususe vokalismis esinevat lahknevust on püüdnud seletada ka Paul Ariste. Algupäraste pikkade vokaalide $\bar{l}$ ja $\bar{u}$ idalätipärane, suhteliselt konsekventne diftongistumine on tema arvates Ilzenes erinevalt Lejasciemsist toimunud seetõttu, et sealsed eestlased on vanemad sisserändajad ja olnud seega pikema aja jooksul lätlastega intensiivses kontaktis kui naaberala eestlased. Sellise oletusega kaasnev vastuoksus - miks eesti keel tugevast läti mõjust hoolimata pidas Ilzenes kõige kauem vastu - on Ariste arvates seletatav sellega, et Ilzene oli läti asustusest eraldatud metsadesoodega. Ent kui arutluse lähtekohaks on siinsete eestlaste põlisasustus, siis Ariste seisukoht ei päde.

Lejasciemsi eestipärased kohanimed on enamasti kohanenud läti morfoloogilise süsteemiga, kuid on huvitavaid erandeid. Zemzare on registreerinud kohanimesid, kus täiendosa on läti kontekstis ebahariliku lõpuvokaaliga $i$, mida saab tõlgendada maskuliinide pluurali nominatiiviks. Nominatiivse täiendosisega sõnaühendid ja liitsõnad esindavad läänemeresoome sõnamoodustusmalli, mis on hästi tuntud läti liivipärases murdekeeles. Lejasciemsi liitnimede täiendosiste grammatilise soo kõikumist, sealjuures meessoo domineerimist, seletab Zemzare õigesti eesti keele mõjuga.

Lejasciemsi kohanimede etümologiseerimisel on Zemzare tõukunud lähtekohast, et igal kohanimel on nimeandmise hetkel tähendus, mis püüab kirjeldada objekti, millele nimi antakse. Zemzare on kõigile läti (balti) kontekstis läbipaistmatutele Lejasciemsi nimedele püüdnud leida häälikuehituselt kokkulangevaid või lähedasi eesti üldnimesid, tuues mõnikord üldnime toeks (lõuna) eesti koha- või ka eesnimesid. Zemzare etümoloogiaid mõneti parandades ja täpsustades ning uusi lisades võin provisoorse analüüsiga tõdeda, et Zemzare kogutud ja publitseeritud kohanimed kätkevad üle saja võimaliku eesti päritolu apellatiivse sõnatüve. On oluline rõhutada, et enamasti on neil apellatiivne vaste lõunaeesti (Võru) murdekeeles. Real juhtudel apellatiivne vaste Võru murdekeeles puudub, kuid on registreeritud Mulgist. Zemzare on püüdnud esile tuua Lejasciemsi kohanimedes esinevaid eesti tuletusliiteid, kuid uurija tagasihoidliku keeleoskuse ja eesti sõnatuletuse vähese tundmise tõttu on analüüs mehaaniline ja tulemus teinekord küsitav.

Edasine hoolikas analüüs toob tõenäoliselt esile kohanimedesse kätketud ja seni tähelepanuta jäänud apellatiive, tuletusliiteid, topoformante vms.

Alūksne koguduse õpetaja Otto Friedrich Paul von Prühl on 1815. a paiku koostanud loendi Kalnamuiža taludest, kus elavad eestlased (34 talu). Heikki Ojansuu teatel, kes 1911. a uurimisreisil käis ka Kalnamuižas, oskasid veel vaid vähesed mingil määral eesti keelt. Ometi on Kalnamuiža eestlased jätnud nimetamisväärse jälje kohalikku läti murdekeelde, kui provisoorseltki ana- 
lüüsida hiljaaegu ilmunud Sarmīte Balode ja Ilga Jansone koostatud sõnaraamatut „Kalnienas izloksnes vārdnīca”. Valdav osa ainestikust on kogutud aastatel 1977-2013. Sõnaraamatus on pearõhk spetsiifilisel lokaalsel sõnavaral. Läänemeresoome, sh lõunaeesti mõju võib täheldada kõigil keeletasandeil. Sõnavara kõrval tuleb substraatnähtustest nimetada abstraktnoomeneid, mis eesti keele eeskujul esinevad murrakus ootuspäraste mitmussõnade asemel ainsussõnadena, nt bàda 'mure, vaev, häda', läti kk bēdas pl jt. Siinsele idaläti murdekeelele on omased läänemeresoome keeltele iseloomulikud põhiverbi ja adverbi ühendid (ühendverbid) ja prefiksverbid, mida saadavad samatähenduslikud adverbid. Jne. Kõnealuse murdesõnaraamatu materjali edasist võrdlevat analüüsi tuleb jätkata, mis tõenäoliselt toob esile uut huvipakkuvat substraatset lõunaeesti keeleainest.

Kohanimed on tõend võimalikust eesti asustusest Vidzeme kagunurga Madona piirkonna seeli murdeala lõunaosas, praeguse haldusjaotuse järgi Mārciena ja Bērzaune vallas, samuti Lazdonas. Kohanimede eesti resp. läänemeresoome päritolu näib toetavat siinsele murdekeelele iseloomulik hääldust hõlbustav siirdevokaal sõnaalgulistes, harvem ka sõnasisestes konsonantühendites. Praegu pole selge, kas tegemist on tõesti põlise lõunaeesti resp. läänemeresoome asustusega või sisserändega. Piirkonna murdekeele ja kohanimistu edasine süstemaatiline uurimine aitaks välja selgitada uusi eesti (läänemeresoome) päritolu kohanimesid ja võimaldaks luua selgema ettekujutuse sealse piirkonna võimaliku eesti (läänemeresoome) asustuse ulatusest ja keelelisest iseloomust.

Märksõnad: kohanimed, etümoloogia, läti murded, lõunaeesti murded, keelesaared 